\title{
Geological Model of Mae Tang-Mae Ngad Diversion Tunnel Project, Northern Thailand
}

\author{
Kan Kaewkongkaew ${ }^{1}$, Noppadol Phien-wej ${ }^{2}$, Thanu Harnpattanapanich ${ }^{3}$, Chinda Sutiwanich ${ }^{3}$ \\ ${ }^{1}$ Royal Irrigation Department, Bangkok, Thailand \\ ${ }^{2}$ Asian Institute of Technology, Bangkok, Thailand \\ ${ }^{3}$ Panya Consultants Co. Ltd., Bangkok, Thailand \\ Email: kanmum49@yahoo.com,noppadol54@gmail.com, thanuhar@loxinfo.co.th, chinda_s@panyaconsult.co.th
}

Received May 23, 2013; revised June 23, 2013; accepted July 25, 2013

Copyright (C) 2013 Kan Kaewkongkaew et al. This is an open access article distributed under the Creative Commons Attribution License, which permits unrestricted use, distribution, and reproduction in any medium, provided the original work is properly cited.

\begin{abstract}
Most of infrastructure projects around the world have to focus on a clear understanding of geological model which may be determined from various sources of information. The limitation in geotechnical data and budget affects the accuracy of the geological model, particularly for projects of long and deep tunnel of which accessibility to the excavation points is difficult and far reaching. Therefore, an approach adopted for interpretation plays an important role in the level of uncertainty of the derived geological model. This paper focuses on the determination of the geological models at the site of a long water diversion tunnel project in a complex geologic setting in northern Thailand from an approach to understand the relationship between regional tectonic setting and local tectonic condition so that geological structures and rock mass conditions along the tunnel alignment can be assessed for a better planning of tunnel design and construction. The paper describes tectonic settings at regional scale (Northern Thailand and Eastern Myanmar), tectonic features and geologic condition in project area, geotechnical investigation and data along tunnel alignment and predicted tunnel ground behavior.
\end{abstract}

Keywords: Geological Model; Tectonic Setting; Tunnel Ground Behavior

\section{Introduction}

Generally, infrastructure projects require an understanding of a clear geological model of the study area which must be carefully determined from various sources of information such as the understanding of tectonic setting, geological and geotechnical site investigation data, laboratory test data, and geologists' experience. Moreover, the budget limitation of a geotechnical site investigation program particularly a tunnel project in a remote mountainous area is a reason of a high uncertainty of the derived geological model. Therefore, an interpretation of all information plays an important role in creating a geological model based on those limited data. A long and deep water diversion tunnel project in mountainous terrain of northern Thailand is an example for this case. The Mae Tang-Mae Ngad diversion tunnel project is designed to convey water from Mae Tang River to Mae Ngad and Mae Kuang reservoirs (Figure 1). It was aimed to augment water supply for people and industry in Chiangmai and Lampun Provinces involving over $25 \mathrm{~km}$ of tunnel in the first leg of the diversion to convey $28 \mathrm{~m}^{3} / \mathrm{sec}$ of raw water from Mae Tang River to Mae Ngad reservoir. The tunnel is located about $55 \mathrm{Km}$ north of Chiangmai city. It follows a west-east alignment from Mae Tang River to Mae Ngad reservoir and traverses Mae Ping River, which is the main river in this region, at $\mathrm{Km} 14+900$ of the tunnel length. Moreover, this tunnel traverses the mountainous terrain at a depth ranging from about 20 to $758 \mathrm{~m}$. The tunnel consists of $4.00 \mathrm{~m}$ inside diameter and the alignment is separated in Triassic granitoid intrusive and felsic volcanic rocks zone (Zone I), Ping River fault zone (Zone II), and sedimentary rocks belonging to the Lower and Upper Palaeozoic zone (Zone III). The geology of the study area is very complex and variable ranging from intact to highly fractured and weathered rock masses which consist of high graded metamorphic rocks such as gneiss, marble and low graded metamorphic rock such as slate and quartzite with a lot of fault and fractures [1]. Carborniferous group contains dominantly thick-bedded sandstone intercalated with shale and siltstone. The sandstone is graywacke in reddish brown, red, gray and dark gray color. Moreover, igneous rock in this area is predominantly granite which intrudes between Mesozoic Era and early Cenozoic Era [2]. The 


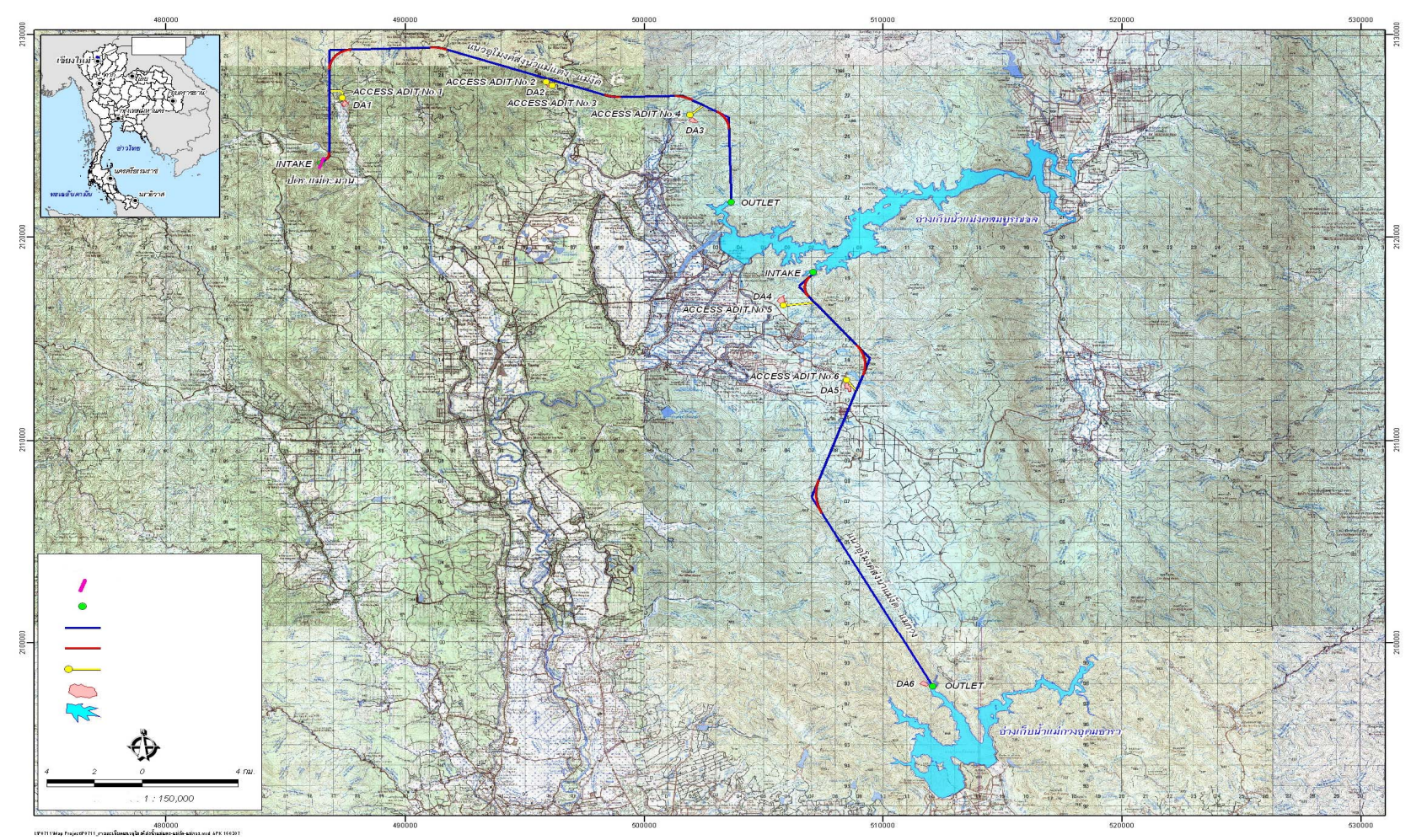

Figure 1. Location of Mae Tang-Mae Ngad and Mae Ngad-Mae Kuang diversion tunnel project.

accuracy of design depends on the reliability of geological features expected along the alignment from the geologic investigation and geological model. This paper focuses on a good understanding on geological model of the project area in view of the past tectonic events. The relationship between regional tectonic setting (Northern Thailand and Eastern Myanmar scale) and local tectonic settings (Chiangmai province) and geological structure data in the study area play an important role to understand the geological model of the study area which is based on the existing data, field investigation data, boreholes data, laboratory test data, and geologists' experience. The concept of geological model for assessment of tunnel ground behavior along the alignment followed the Austrian Guideline for the Geotechnical Design of Underground Structure [3].

\section{Regional Tectonic Setting}

Thailand and adjacent area were interpreted as being the product of the collision between several micro continents [4]. The tectonic models of Southeast Asia including Thailand were proposed by several authors [4-14]. The convergence and collision of Shan Thai block in the West and the Indosinia block in the East play an important role for eastward subduction and undertrusting during late Paleozoic-early Mesozoic events resulted in a developing fold thrust belt as show in Figures $\mathbf{2}$ and $\mathbf{3}$ $[15,16]$. Moreover, [17] reported that this belt is com- posed largely of granite gneiss, which has been thrusted westward over Paleozoic limestone. The granitic intrusions, which were followed by general uplift, associated the Triassic collision. Thereafter, relatively stable conditions prevailed. There was again overthrusting further west in the Late Triassic and Early Jurassic [18].

The cause of complex geological structure started from the collision of the Shan Thai block and the Indochina block created a mobile thrust belt during late Palaeozoicearly Mesozoic events $[5,4,19,20]$ which was intruded by Triassic granitoids as well as the Carboniferous intrusive complex [21]. Thereafter, relatively stable conditions prevailed. Then, continuing convergence in the west of Thailand caused folding which has decreased towards the East [18]. In Late Cenozoic tectonic events, Southeast Asia was pushed south-eastwards and rotated. As a result of this collision strike-slip faults oriented NW-SE and NNE-SSW trending were produced [12,22].

Reference [6] proposed reconstruction of Southeast Asia tectonic history which started from high convergence rate and NE-SW convergence direction of India plate to Eurasia plate during Late Mesozoic. It changed to a more northerly direction during the Early Oligocene, resulting in a major episode of southeastward extrusion of Indochina as well as seafloor spreading in the South China Sea. This changing caused a termination of southeastward extrusion of the Indochina micro-plate in the Early Miocene because of no longer in contact between 


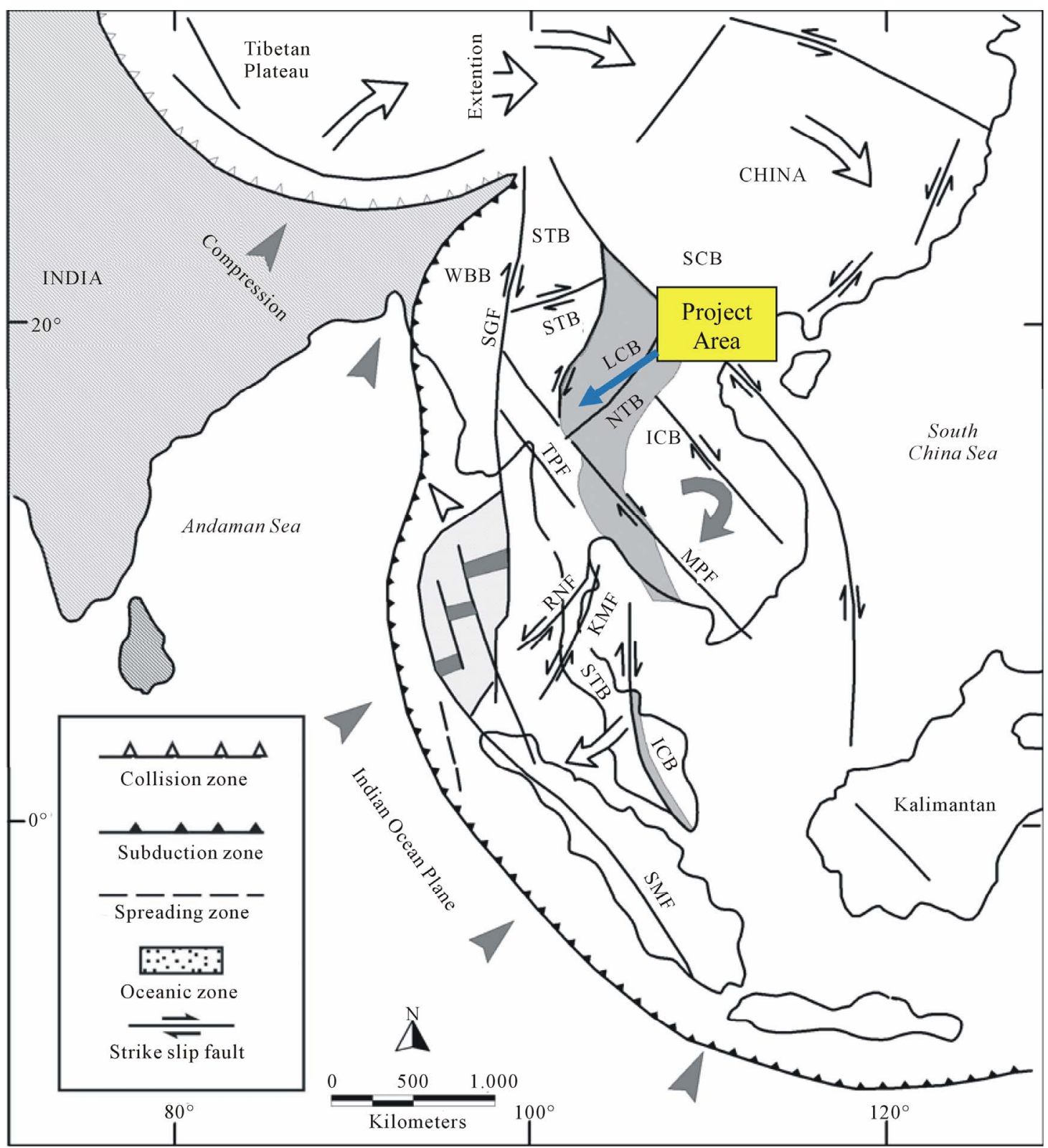

Figure 2. Tectonic map of SE Asia showing major fault systems and the relative movement of crustal blocks in response to India-Asia collision (modified from [22]).

Indian plate and Sino-Burma-Thailand and Indochina micro-plates. At the same time, South China block extruded to the east faster than the Indochina micro-plate because of northward directed collision between Indian and Eurasian plates resulting in changing direction of major strike-slip faults. Northwestern mountain range represents a large-scale mantled gneiss dome which is [23] composed of a core of granite migmatites or gneisses overlain by a layered metasedimentary or metavolcanic cover or mantle. This is a simple domal structure but it has a complex internal deformation history illustrated by minor folds of different styles and orientation [23]. Moreover, [24] concluded that the main gneiss-forming metamorphic event was in the Late Triassic-Early Jurassic. Then, the collision between Indian and Eurasian plates pass-through western Burma micro-plate that was subducted underneath the Shan-Thai micro-plate, creating the cretaceous metamorphic core complex belt along the western border of Thailand and eastern Myanmar during Late Cretaceous and Early Miocene with detachment faulting [2]. Although the original tectonic events in northern Thailand that predominate geological structure in this area are poorly understood, there are several possible models to explain the tectonic events during Late Mesozoic-Cenozoic [6,11,25-27]. One explanation could be that crustal thickening, uplift and igneous intrusions as- 


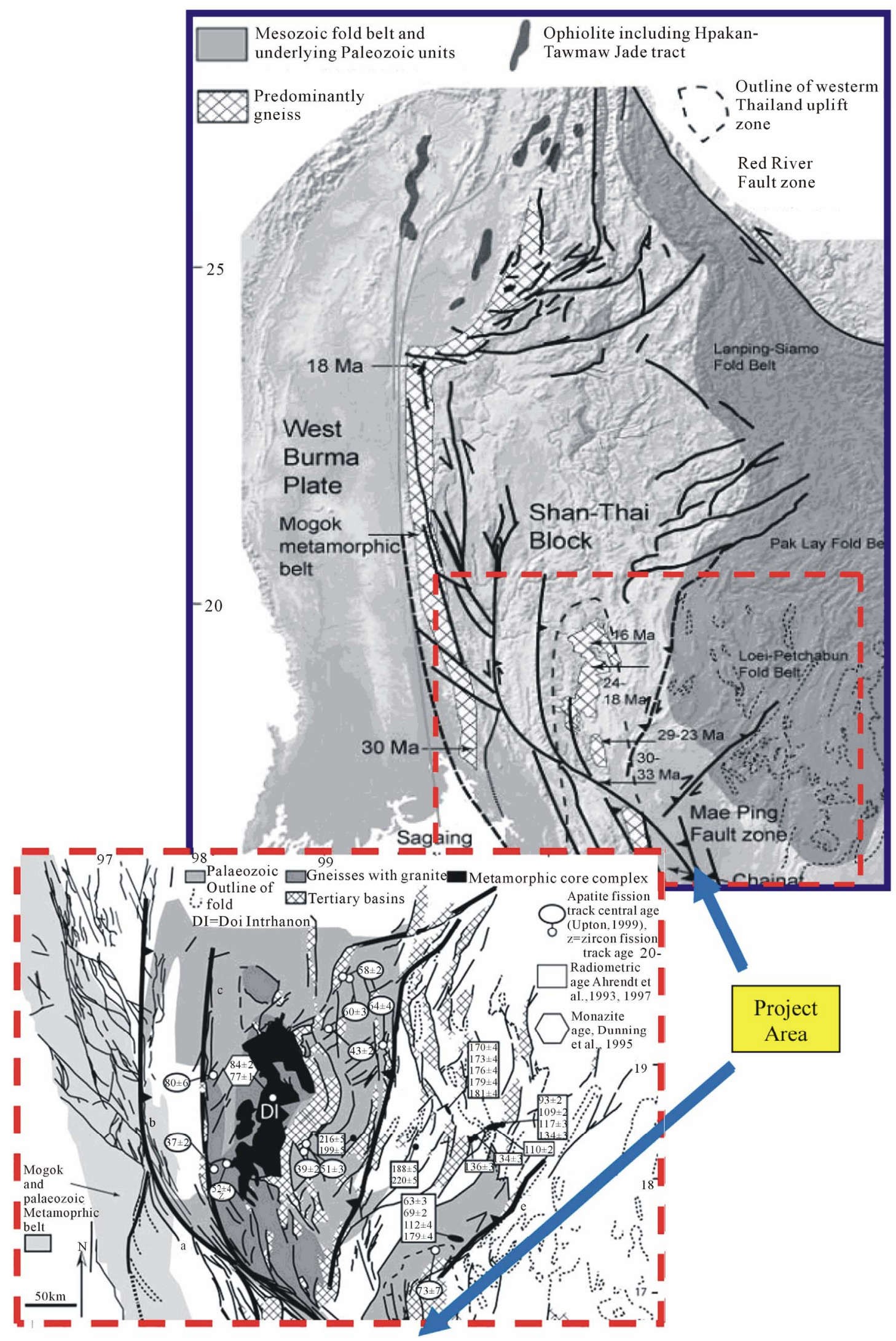

Figure 3. Thrusts shown by bold black lines indicate possible major oblique reverse faults, which have restraining geometries under left lateral motion on NW-SE-striking strike-slip faults [32]. 
sociated with the Eocene-Early Oligocene transpression created sufficient gravitational potential and lithospheric instability to generate metamorphic core complexes by a decrease in E-W compressive stress as India moved further north. Another possible explanation of the metamorphic core complexes is that non-uniform lithospheric stretching related to subduction rollback resulted in anomalous lower lithospheric thinning under the Doi Suthep and Doi Intanon areas. Consequently, the crust was heated, isostatically uplifted and partially melted resulting in the emplacement of Oligocene granites [27]. This was supported by the information of Doi Inthanon and Doi Suthep core complexes that have been documented by several authors [2,23,28-30]. Moreover, [31] proposed that the western gneiss belt in northern Thailand can be subdivided into northern extensional (study area) and southern shear zone domains.

The collision of India and Eurasia plates during Late Mesozoic and Early Cenozoic produced an E-W compression in northern Thailand resulting in movement of sinistral strike-slip faults in NW-SE trend (Mae Ping fault) and movement of dextral strike-slip faults in NESW trend (Mae Chan fault) [12,20,22,25]. Moreover, the movement of Mae Ping fault resulted in the left lateral offset of the metamorphic core complex belt and also the movement of Mae Chan fault result in the right lateral offset of this belt in northern part of Chiangmai Province [20]. This compressive stress should create thrust fault in $\mathrm{N}-\mathrm{S}$ trending ([10]; Figure 3). Moreover, there are evidence of thrust fault in northern Thailand such as thrust along Nan Suture Zone [13]; N-trending Mae Hong Son fault and thrust [32]; thrust of Ob Luang gneiss at Hot District, Chiang Mai Province [33]; a frontal trust and folding zone [34]; thrust and reverse fault in the Inthanon zone [35]. Then, the change in stress pattern from E-W compression to nearly N-S compression during the Early Miocene resulted in changing the movement of major strike-slip faults into opposite direction in northern Thailand also accompanied the regional E-W extension during the Late Oligocene to Early Miocene initiated the formation of Tertiary basins in northern Thailand $[20,25,26,36]$.

In addition, [27] discussed that the strike-slip faulting may have more than one origin including : 1 ) reactivation of older strike-slip trends during phases of inversion ; 2) strike-slip transfer faults between large extensional faults; 3) oblique-slip transtensional faults, where extensional faults followed pre- existing fabrics oblique to the regional extension direction. Therefore, [27] concluded that the relationship between strike-slip faults and rift basins in terms of timing of extensional and inversion is more complex than it can be explained by simple escape tectonic models which were proposed by several authors [7,8,12,37,38]. Moreover, [25] discussed that dominated deformation in northern Thailand was the transitional ex- tensional zone which played dominant role from strikeslip dominated deformation in Yunan in Southern China and extensional dominated deformation in northern Thailand. Furthermore, [26] proposed that based on data from Mae Kuang fault which indicated the strike-slip of northern Thailand it accommodates differential slip and rotation between adjacent sub-blocks involved in the tectonic extrusion of Indochina. Therefore, the recently tectonic models of SE Asia and the study area cannot be used to explain most of geological structure in this area. The combinations of tectonic models are appropriate to explain the regional tectonic events around the study area. Moreover, geology data should be combined with regional and local tectonic information for creating geological model of the study area.

\section{Geologic Condition of Project Area}

Geology of surrounding Chiang Mai Basin can be grouped roughly into two parts; the Paleozoic rock and rock of the Tertiary and Quaternary Periods [21]. Reference [39] described that the basement rocks of south-central Chiangmai basin are interbeded conglomerate, sandstone and shale of Cretaceous age. Moreover, those basement rocks can also be inferred from exposures in the uplands that surround the basin. Lithologies of western Chiang Mai basin include variably metamorphosed limestone- marble, gneiss and schist which are intruded by Triassic granitoids as well as the Carboniferous intrusive complex [21], East of the Chiang Mai basin consists of unmetamorphosed Ordovician sandstone and shale of the Mae Tha Formation [40] and upper Palaeozoic mafic volcanic rocks of the Chiang Mai belt. Moreover, result of boreholes data in Chiang Mai basin indicated that pre-tertiary rocks are Carboniferous sediments and volcanics rocks [41].

Thung Song Group which belongs to the later part of the Ordovician possibly extending into the Silurian, is the oldest rocks in the project area. Limestone with some shale horizons are mainly rocks of this group. Then, the pelagic sedimentation spread and continued into the Devonian. The prevailing rock is sandstone or slightly metamorphic sandstone. Occasionally, limestone deposit in a shelf environment occurs. Moreover, the clastic marine sedimentary rocks, known as the Thong Pha Phum Group, conformably overlies the Thung Song Group [16]. This group is interpreted as having been deposited itself to back-arc settings during Siluro-Devonian, extending up into the Caboniferous in places. Sandstone, shale (siltstone) are mainly rocks of this group.

Various Carboniferous-Permian sequences overly the Thong Pha Phum Group. Limestone was deposited in the Late Carboniferous. Moreover, there are some red beds in the uppermost Carboniferous with the characteristics of an extensional continental setting which mostly occur 
in sedimentary zone near Mae Kuang reservoir. Rocks of this sequence are mainly sandstone, shale (siltstone) and limestone of mainly Lower-Middle Permian age, which forms striking karst landscapes wherever it crops out. Then, large areas were uplifted to form highlands in the Pliocene to early Pleistocene. Weathering process and the formation of slope debris and river deposits developed into the Holocene [16]. The lithology of the project area can be divided into three zones as shown in Figure 4 that are Triassic granitoid intrusive and felsic volcanic rocks zone (Zone I), Ping River fault zone (Zone II), and sedimentary rocks belonging to the Lower and Upper Palaeozoic zone (Zone III). There are mainly igneous and metamorphic rocks such as granite and marble in zone I which is highly fractured and local faults. The influence of granitiod intrusion and tectonic faulting and folding on the rock mass structure affect to highly variable dip orientation and angle of bedding planes. Next in zone II, there is a highly tectonically disturbed boundary zone which is a large fault zone along Ping River. This zone consists of many rocks type such as sedimentary, metasedimentary, and metamorphic rocks which are mostly pyrite, calesilicate, metasiltstone, and metasandstone. However, the geological structure was influenced by complex tectonic impact resulting in variation of dip and strike directions and several joint zones. Most of fault zones are located in this zone because there are influences from several oblique strike-slip faults. Finally, in zone III compose of metasandstone, quartz wacke and pebbly sandstone. There are fewer joints of rock mass because of local influence of moderate to slightly tectonic disturbance.

\section{Tectonic Approach and Geological Structure of Project Area}

Reference [41] indicated that there are many faults and movements in Chiang Mai basin. Therefore, the geological structures are separated into several blocks and compartments, resulting in more complex structures which were documented by several authors [9,11,13,27,29,42]. Moreover, the west of the Chiang Mai basin is a region of high-grade metamorphic rocks that are overlain by a detached cover of low-grade Palaeozoic metasedimentary rocks of the Shan Thai terrain as Doi Suthep and Doi Inthanon metamorphic core complex, north and west of Chiangmai city. Those metamorphic core complex may represent the mid-crustal extension of a detachment fault that accommodated major approximately east-west crustal extension $[23,30]$. Consequently, northern Thailand is interpreted to represent a region of predominantly extensional tectonics associated with strong oblique preexisting fabrics [25]. Moreover, [25] suggested that extensional stress in northern Thailand have dominated over the strike-slip dominated stress systems. Although the stress system of northern Thailand may seem to dis- play classic simple strike-slip characteristics, this belies the complexity of tectonic events recorded in the basins such as Mae Moh and Li Basins to the south of the project area and Fang basin to the north $[27,43]$. The outcrop data from coal mines in $\mathrm{Li}$ Basin indicated the oldest structure unit is deformed by numerous normal faults, thrust faults and folds of multiple orientations. Conversely, the youngest structure unit below the Quaternary gravels displayed very simple broad, open folds and a few minor normal faults [43]. North-south to NW-SE trend is main directions of normal faults. While main directions of thrust faults are NE-SW to ENE-WSW, E-W and NNW-SSE [43]. In particular the NNW-SSE normal fault trend seems to be favored. Moreover, the evidence of E-W thrust faults is shown in Li Basin, Northern Thailand which related to changing in stress pattern during Late Oligocene to Early Miocene [43]. These thrust faults were predominated by at least five times of inversion in Li Basin. Moreover, [27] and [44] showed evidence of regional basin inversion resulting in folding, some reactivation of normal faults as thrusts in Chiang Mai basin and the vicinity. The inversion events related to geological structure along tunnel alignment at road cut near Mae Ping river $(\mathrm{km} 14+900)$, and Mae Rerm reservoir $(\mathrm{km} 19+500)$ that are the tectonic impact by thrust faults lied near E-W trending (Figure 5). However, evidence of thrust fault along tunnel alignment related only with minor tectonic events. Moreover, the data of boreholes from Mae Tang-Mae Ngad and Mae Ngad-Mae Kuang diversion projects showed similar information. Although, there are no more evidence to support the relationship between geological structure along Mae Tang-Mae Ngad and Mae Ngad-Mae Kuang projects, this belies the relationship on the tectonic events between both projects which were supported by a similarity of data from boreholes. Reference [16] indicated some evidence of the thrust system in Mae Ngad-Mae Kuang Diversion Tunnel Project. Frequent core loss, abundant fault gouge as well as extremely low RQD values reflect the intense tectonic impact on the rock mass by thrust faulting. The evidence of thrust fault contact is found in a borehole in the area (Figure 6). The mudstone/shale has been altered close to the fault contact, which is indicated by the discoloration from an original reddish color to a light brownish grey. Moreover, the core reflects the complex and heterogeneous composition of the rock mass within the thrust fault complex. Intensely karstified linestone boulders of variable size and portions of intact rock mass (e.g. sandstone, shale) are embedded in the fault gouge material. The thrust fault complex is terminated at approximately the middle of tunnel alignment by a system of strike-slip fault, which displaces the fault rocks of the thrust zone against sandstone and shale. Moreover, geotechnical data in Mae Tang-Mae Ngad diversion tunnel project showed similarity of fault contact 


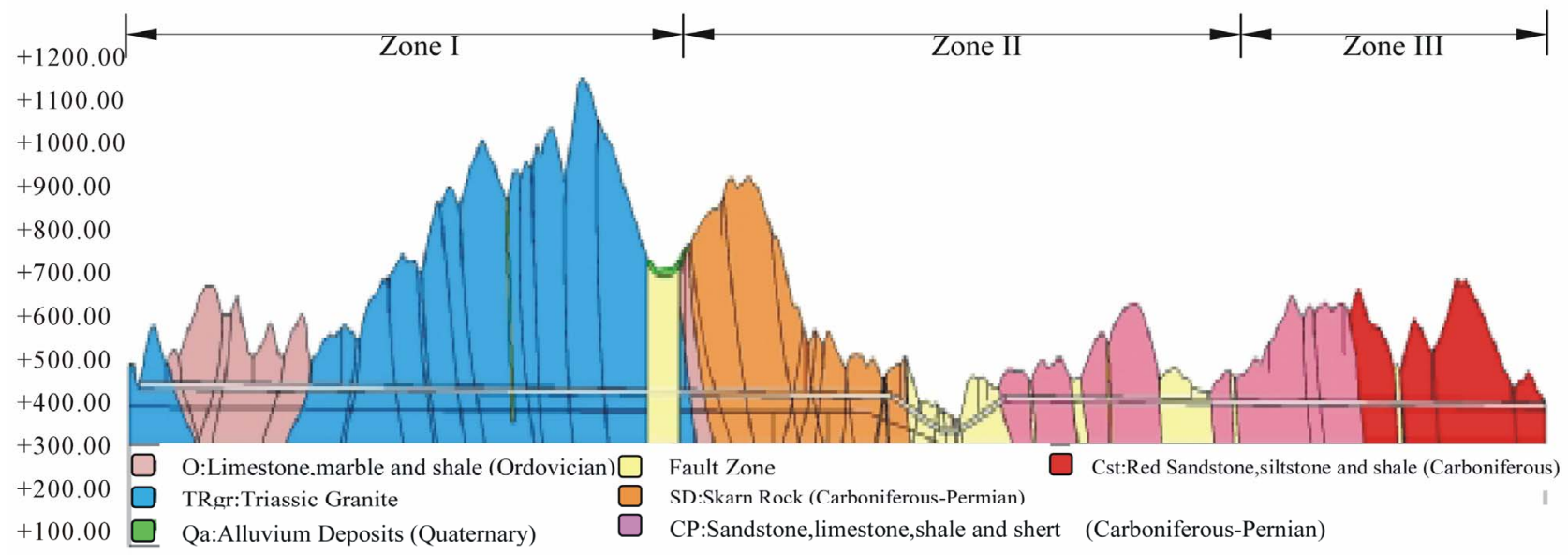

$0+000 \quad 1+000 \quad 2+000 \quad 3+000 \quad 4+0005+000 \quad 6+000 \quad 7+000 \quad 8+000 \quad 9+000 \quad 10+00011+00012+00013+00014+00015+00016+00017+00018+00019+00020+00021+00022+00023+00024+00025+000$

Figure 4. Geology of Mae Tang-Mae Ngad diversion project.
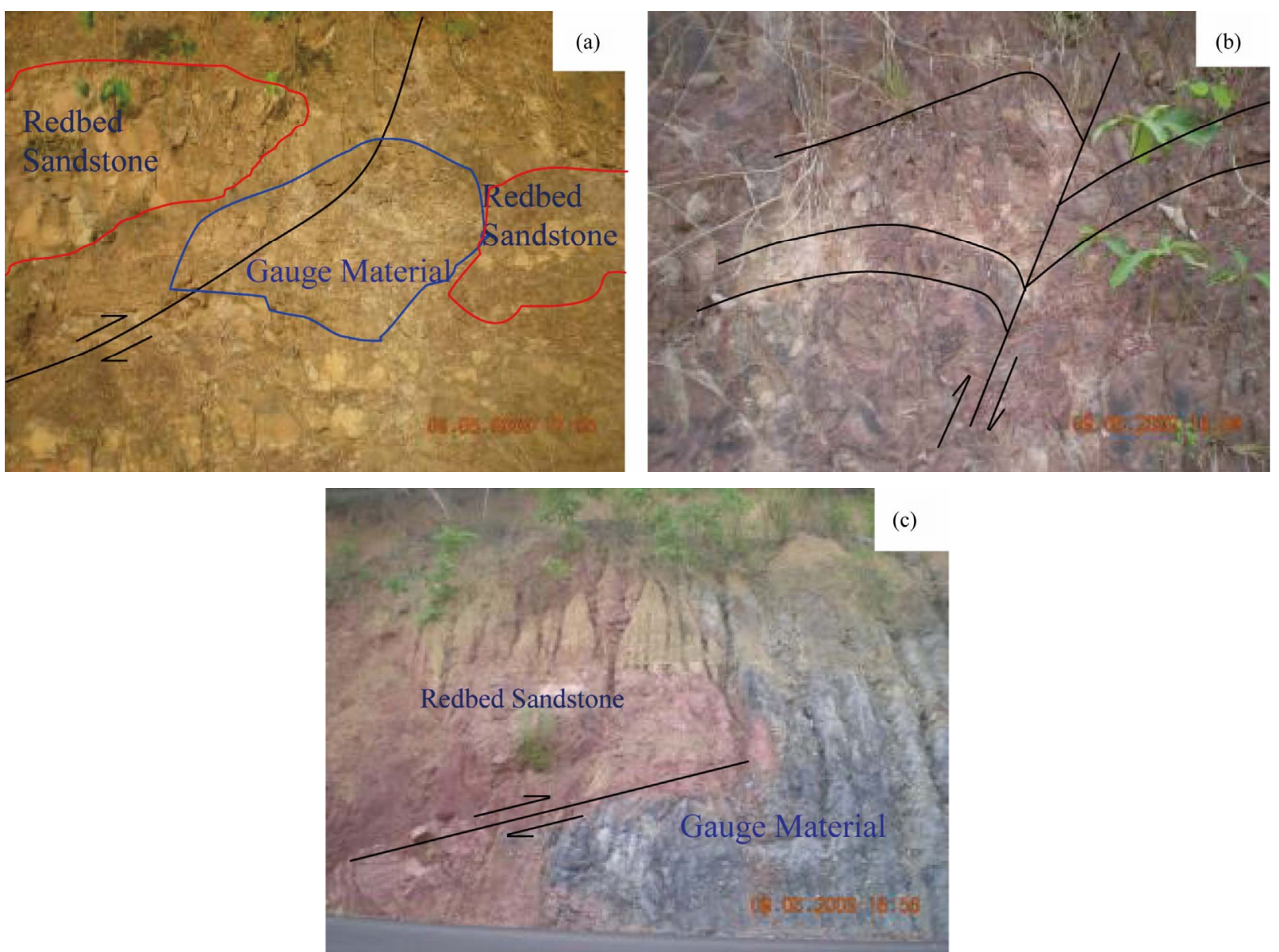

Figure 5. Evidence of minor thrust faults along road cut at Mae Ping River (km. $14+900)$.

in zone I (km 9.92 - km 20.00) which showed frequent core loss, abundant fault gouge as well as extremely low RQD values, reflecting the intense tectonic impact on rock mass by faulting. However, no clear evidence of thrust fault contact was found in this project site. In addition, the evidence from [18] which explained the cause of folding affecting the Mesozoic molasses formation decreasing towards the East, were supported by field observation data in the project in that more folding and fault zones exist from km. $0+000$ to $20+000$ and then decreases to 


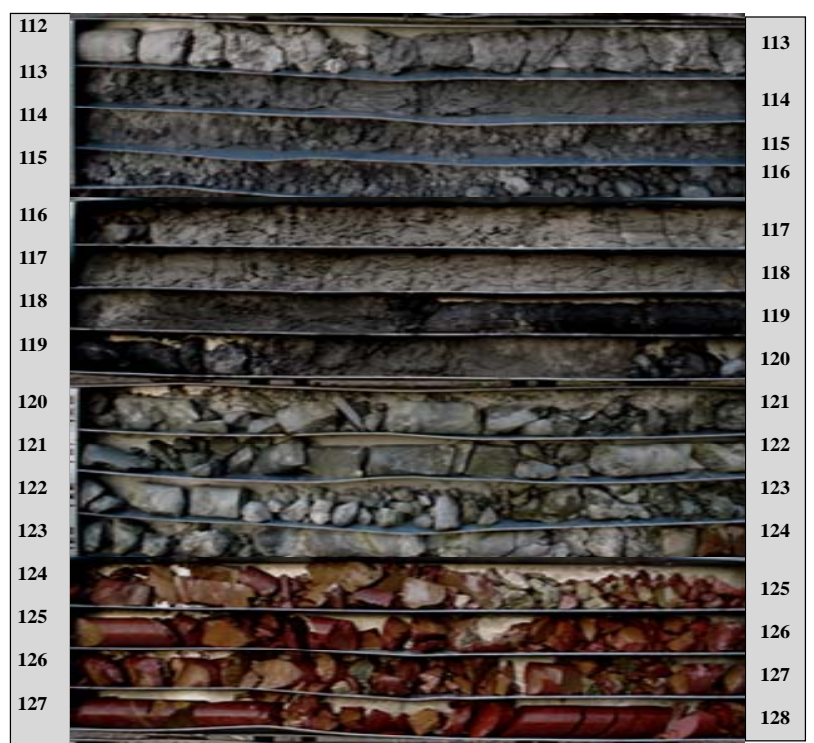

Figure 6. Quartzitic sandstone/fault gouge thrusted on top of red shale in the borehole data (dhw-5) of Mae Ngad-Mae Kuang diversion project, depth: 112 m - 128 m.

the end of tunnel. The complex geology is mostly in Triassic granitoid intrusives and felsic volcanic rocks zone (zone I) and Ping River fault zone (zone II) which are in the West. It decreases towards the East in sedimentary rocks zone (zone III). Moreover, there are metamorphic and granites intrusion events related to geological structure at $\mathrm{km} 0.00-9.27$ which is granite intrusion into limestone or Paleozoic rock resulting in the rocks in this zone to have different dip and strike directions. Moreover, there is migmatite which is a rock at the frontier between igneous and metamorphic rocks. Migmatites formed under extreme temperature conditions during prograde metamorphism, where partial melting occurred in preexisting rocks.

\section{Geotechnical Condition along Tunnel}

Although geotechnical and engineering geology data are very important for the project's success, the budget limitation is even more important for geotechnical investigation program in developing countries. As geotechnical investigation program in Mae Tang-Mae Ngad diversion project with only $2705 \mathrm{~m}$. of boreholes, resistivity, seismic refraction and geology field mapping along tunnel alignment. The total length of boreholes represents only 10 percent of the tunnel length that is 25,643 $\mathrm{m}$ long. This is different from several projects in other countries that investigated more than 100 percent of the tunnel length. Seismic refraction is used to determine only for shallow soil and weathering rock layers. It cannot be applied for deep ground layer which is at the tunnel position. Therefore, seismic refraction data cannot be a representative of geological data at the tunnel position. Although geological field mapping is applied to determine surface geology data along tunnel alignment, all surface geology data cannot be determined because of vegetation covers. Therefore, geology data was determined only along the valley, check points and road cut. While the budget of geotechnical investigation program in many developed countries is around $1.5-2.25$ percent of the construction cost [45], this budget is more than enough to be used for interpretation a geological model of study area. Conversely, the budget of geotechnical investigation program in Mae Tang-Mae Ngad diversion tunnel project is limited to be used for data collection. Therefore, the interpretation of geological model (Figure 4) in this project is mostly based on boreholes data, geological field mapping, laboratory testing result, and geologist opinion of Panya Consultant Co., Ltd.

All geological data such as boreholes data, geological field mapping and laboratory testing result (Table 1) are determined for a good understanding in geological model in the study area. The result of laboratory testing shows a high quality of rock properties in zone I, moderate quality in zone III and low quality in zone II respectively. This is related to geology features along the tunnel alignment which are good rock in zone I, fair rock in zone III and weak rock in zone II. The lithology of the project area can be divided into three zones as shown in Figure 4. Firstly, from the inlet to approx. km 9.92 the alignment traverses there are mainly highly fractured and local faults. Moreover, there is a fault zone at $\mathrm{km} 9.27$ 9.80 that may be a contact of granite and marble. However, there are indistinct evidence of contact position and type of fault. In this zone the dip orientation and angle of bedding planes is expected to be high variable due to the influence of granitiod intrusion and tectonic faulting and folding on the rock mass structure. The evidence is shown in the borehole (DHT-7/1) km $9+918)$. There are highly variable of angle of foliation and slickenside due to many depths. There are folding on the rock mass structure due to granitoid intrusion and oblique strikeslip faults [26] resulting in the contact of metamorphic and granite rocks to be a metamorphic aureole and it is folded by compression of a granite rock mass. Most faults are expected to run perpendicular to the tunnel alignment. The risk of tunneling through the fault is considered to be low. However, ground water plays an important role for tunnel excavation because reveling ground and flowing ground may occur in this fault zone as much as in impure marble zone at $\mathrm{km} 0.55$ - 3.04 that karst zone and flowing ground can be found. The tunnel alignment at borehole DHT-7/1 cuts through the contact of metamorphic aureole between marble and granite. Most of granite is the melting of metamorphic rock around this area. Secondly, the tunnel along km 9.92 20.00 will be excavated through different rocks such as 
Table 1. Engineering properties of Mae Tang-Mae Ngad diversion tunnel project.

\begin{tabular}{|c|c|c|c|c|c|c|c|c|c|c|c|c|c|c|c|}
\hline \multirow[t]{2}{*}{ Properties } & \multicolumn{5}{|c|}{ Zone I } & \multicolumn{5}{|c|}{ Zone II } & \multicolumn{5}{|c|}{ Zone III } \\
\hline & No.of & Mean & Max. & Min. & Stand. & No.of & Mean & Max. & Min. & Stand. & No.of & Mean & Max. & Min. & Stand. \\
\hline & Sample & & & & & Sample & & & & & Sample & & & & \\
\hline $\mathrm{p}$ & 187 & 138.55 & 304.80 & 16.56 & 54.69 & 41 & 56.77 & 240.00 & 8.40 & 67.05 & 72 & 84.09 & 288.00 & 8.40 & 63.80 \\
\hline $\begin{array}{l}\text { Tangent Yong's } \\
\text { Modulus,Et(Gpa) }\end{array}$ & 34 & 52.54 & 93.48 & 13.93 & 20.08 & 12 & 14.65 & 39.29 & 1.75 & 10.07 & 18 & 31.58 & 79.58 & 9.72 & 17.00 \\
\hline $\mathrm{C}_{\text {peak }}(\mathrm{Mpa})$ & 13 & 0.17 & 0.43 & 0.00 & 0.12 & 9 & 0.18 & 0.43 & 0.00 & 0.14 & 10 & 0.10 & 0.21 & 0.04 & 0.06 \\
\hline$\varnothing_{\text {peak }}(\mathrm{Mpa})$ & 13 & 36.90 & 44.51 & 29.38 & 4.74 & 9 & 32.08 & 38.20 & 25.26 & 4.97 & 10 & 35.99 & 45.96 & 30.41 & 4.37 \\
\hline Poisson's Ratio & 9 & 0.12 & 0.23 & 0.05 & 0.06 & 0 & 0.00 & 0.00 & 0.00 & 0.00 & 11 & 0.12 & 0.16 & 0.05 & 0.04 \\
\hline $\begin{array}{l}\text { Cerchar Abrasivity } \\
\text { Index }\end{array}$ & 11 & 4.11 & 5.50 & 1.00 & 1.36 & 0 & 0.00 & 0.00 & 0.00 & 0.00 & 5 & 2.90 & 4.50 & 0.50 & 1.80 \\
\hline $\begin{array}{l}\text { Tensile Strength } \\
\text { (BTS) (Mpa) }\end{array}$ & 15 & 3.69 & 6.00 & 0.40 & 1.79 & 3 & 1.13 & 2.20 & 0.20 & 1.01 & 4 & 3.98 & 12.90 & 0.40 & 5.97 \\
\hline
\end{tabular}

sedimentary, metasedimentary, and metamorphic rocks. In this zone there is highly tectonically disturbed boundary zone. Specially, large fault zones along Ping River and Mae Rerm reservoir. Most faults are expected to run almost perpendicular to the tunnel alignment. However, they vary in dip directions because of folding in this zone. The rock mass has instability along fault zone and several joint zones. Therefore, the tunnel may collapse in case of shallow shear failure and deep seated shear failure. In addition, at the siphon tunnel passing through Ping River at km 13.42 - 15.60, there are both thrust and normal faults which were invested from field investigation along the road cut near Mae Ping River (Figure 5). However, the field investigation data showed only thrust and normal fault which were predominated by minor tectonic events or due to reversion time [9]. Borehole data along Ping River indicated that red bed sandstone was put on sandstone and grey siltstone. These can be explained that several oblique strikes-slip faults occurred along this zone resulting in complex geological structures in this area. According to the study of aerial photographs, highly fractured rock mass and variable faults directions are supported by the origin of fault zone in this area. Moreover, ground water level along the tunnel alignment relates to water level of Ping River. Therefore, flowing ground may occur during tunnel excavation. Moreover, the tunnel along $\mathrm{km} 15.60$ - 20.00 will be excavated through different rocks such as pyrite, cale-silicate, metasiltstone, and metasandstone which have several joints and folds. There are two main directions of faults that are NW-SE and NE-SW directions, appearing perpendicular to the tunnel direction. More- over, there are large zone of fault gouge in some places. Specially, In Mae Rerm reservoir zone, fault gauge zone was discovered $(\mathrm{km} .18+$ $500-\mathrm{km} .19+500)$ that may result in flowing ground from ground water problem. The complex geological structure is expected in this zone due to the influence of several oblique strike-slip faults resulting in large fault zone. Finally, the tunnel will be excavated through meta sandstone, quartz wacke and pebbly sandstone along km 20.00 - 25.64. In this section, there are fewer faults and folding which are mostly cut perpendicular to the tunnel direction. Most of rock mass structure is sheared resulting in folding rock. However, the rock mass shows local influence of moderate to slight tectonic disturbance. Moreover, the tunnel may collapses in case of sliding along rock bedding and fault zones.

In addition to the geological and geotechnical condition along the first leg of the diversion tunnel project from Mae Tang River to Mae Ngad Reservoir, the condition along the second leg of the tunnel, Mae Ngad-Mae Kuang reservoirs diversion tunnel was also assessed and the outcome is described heareafter. The geological condition along the tunnel alignment can be divided into three sections. Firstly, from the inlet to approx. Km 6.7 the alignment traverses mainly highly fractured and locally faulted quartzitic sandstone with shale and siltstone intercalations. Between the inlet portal and approx. Km 1.0 the dip orientation and angle of bedding planes is expected to be highly variable due to the influence of tectonic faulting and folding on the rock mass structure. The risk of tunneling through the thrust fault boundary between the Carboniferous sandstone on top of a wide thrust zone (faulted shale-chert-sandstone-(Permian) limestone sequence) is considered to be low. According to the drilling results, along the tunnel alignment the thrust fault contact is located below the tunnel invert. In combination with the fault zones, highly concentrated inflow of ground water to the tunnel has to be expected, with peak inflows in the range up to some $100 \mathrm{l} / \mathrm{s}$ and with a slow decrease due to a rather high volume of the fault and joint bounded aquifers. The main geotechnical Problems will be linked to the intense jointing to fracturing of the rock mass, causing instable conditions along the tunnel side walls and crown of the tunnel as well at the tunnel face. Secondly, tunnel section from approx. $\mathrm{Km} 6.7$ to approx. Km 11.3 is lo- 
cated in remarkable heterogeneous thrust fault zone. It consists of limestone blocks, varying in sizes from hundreds of meters to decimeters, which are embedded in sheared shale, chert and sandstone. The limestone blocks usually show karst features such as corroded joints, pipes as well as caves. In case that karstified limestone is encountered at tunnel elevation, high water inflow of up to some $100 \mathrm{l} / \mathrm{s}$ can be expected. The thrust fault complex is terminated at approx. Km 10.7 by a system of strike-slip fault (approx. Km 10.7 to $\mathrm{Km} \mathrm{11.3)} \mathrm{which} \mathrm{displaces} \mathrm{the}$ fault rocks of the thrust zone against sandstone and shale. The main geotechnical problems of this section include abrupt changes of weak/soft and strong / brittle rock mass, mixed-face conditions, difficulties with groundwater and highly unpredictable uncertainties. Finally, tunnel section from approx. Km 11.3 to outlet ( $\mathrm{Km} \mathrm{23.0)}$ is followed by quartzitic sandstone with shale intercalations from highly tectonically disturbed boundary zone, which continues to approx. Km 11.5 The high inflow of groundwater to the tunnel has to be expected, with peak inflows in the range up to some $100 \mathrm{l} / \mathrm{s}$, and with a slow decrease due to a rather high volume of the fault and joint bounded aquifers. The main geotechnical problems will be similar to the first section.

\section{Conclusion}

Although there is a poor understanding of tectonic events in northern Thailand, this study creates a better understanding of relationship between regional and local tectonic events which predominate to geological structure in the study area due to data limitation. Field observation data support the complex geological structure in this area which is predominated by several tectonic events resulting in different geology features along the tunnel alignment such as several thrusts and normal faults, granite intrusion zones, and metamorphic core complex zones. Moreover, geotechnical data from field observation and laboratory testing indicate that the main problems of tunnel construction relate to large faults such as karst topography fault, Ping River fault zone, and Mae Rerm reservoir fault gauge zone. Those will create reveling ground and flowing ground resulted from ground water problem. The following major results of this study help constrain the geological structure in the study area and provide focus for tunneling design and construction work.

\section{Acknowledgements}

The Mae Tang-Mae Ngad diversion tunnel project was supported by Royal Irrigation Department, Thai Government. I would like to thank Dr. P. Noppadol, Dr. H. Thanu, and S. Chinda for consultant of paper writing, staffs of Panya Consultants Co., Ltd. for comment and supportive information.

\section{REFERENCES}

[1] C. Lee and T. Charoenmit, "Geology of Mae Ping Basin, Scale: 1: 50000,” Changwat Chiang Mai, Amphoe San Pa Tong, Amphoe San Sai, and Changwat Lamphun, 2004, pp. 213-218.

[2] G. R. Dunning, A. S. Macdonald and S. M. Barr, “Zircon and Monazite U-Pb Dating of the Doi Inthanon Core Complex, Northern Thailand: Implications for Extension within the Indosinian Orogen,” Tectonophysics, Vol. 251, No. 1-4, 1995, pp. 197-213. doi:10.1016/0040-1951(95)00037-2

[3] Austrian Society for Geomechanics, "Guideline for the Geomechanical Design of Underground Structures,” Austrian Society for Geomechanics, Salzburg, 2001.

[4] O. M. Ferrari, C. Holchard and G. M. Stampfli, “An Alternative Plate Tectonic Model for the Palaeozoic-Early Mesozoic Palaeotethyan Evolution of Southeast Asia (Northern Thailand-Burma)," Tectonophysics, Vol. 451, No. 1-4, 2008, pp. 346-365.

[5] P. Charusiri, B. P. Rhodes, P. Saithong, S. Kosuwan, S. Pailophi, W. Wiwegwin, V. Doarerk, C. Hinthong and S. Klaipongpan, "Regional Tectonic Setting and Seismiicity of Thailand with Reference to Reservoir Construction," GEOTHAI'07 International Conference on Geology of Thailand: Towards Sustainable Development and Sufficiency Economy, Bangkok, 21-22 November 2007, pp. 274-287.

[6] T. Y. Lee and L. A. Lawver, "Cenozoic Plate Reconstruction of Southeast Asia,” Tectonophysics, Vol. 251, No. 1-4, 995, pp. 85-138. doi:10.1016/0040-1951(95)00023-2

[7] P. Molnar and P. Tapponnier, "Cenozoic Tectonics of Asia: Effects of a Continental Collision,” Science, Vol. 189, No. 4201, 1975, pp. 419-426.

[8] P. Molnar and P. Tapponnier, "The Collision between India and Eurasia," Scientific American, Vol. 236, No. 4, 1977, pp. 29-41.

[9] C. K. Morley, S. Gabdi and K. Seusutthiya, "Fault Superimposition and Linkage Resulting from Stress Changes during Rifting: Examples from 3D Seismic Data, Phitsanulok Basin, Thailand,” Journal of Structural Geology, Vol. 29, No. 4, 2007, pp. 646-663. doi:10.1016/j.jsg.2006.11.005

[10] C. K. Morley, “Nested Strike-Slip Duplexes, and Other Evidence for Late Cretaceous-Paleogene Transpressional Tectonics before and during India-Eurasia Collision, in Thailand, Myanmar and Malaysia,” Journal of the Geological Society of London, Vol. 161, No. 5, 2004, pp. 799812. doi:10.1144/0016-764903-124

[11] C. K. Morley, "A Tectonic Model for the Tertiary Evolution of Strike-Slip Faults and Rift Basins in SE Asia," Tectonophysics, Vol. 347, No. 4, 2002, pp. 189-215. doi:10.1016/S0040-1951(02)00061-6

[12] S. Polachan, S. Pradidtan, C. Tongtaow, S. Janmaha, K. Intarawijitr and C. Sangsuwan, "Development of Cenozoic Basins in Thailand,” Marine and Petroleum Geology, 
Vol. 8, No. 1, 1991, pp. 84-97. doi:10.1016/0264-8172(91)90047-5

[13] S. Singharajwarapan and R. Berry, “Tectonic Implications of the Nan Suture Zone and Its Relationship to the Sukhothai Fold Belt, Northern Thailand," Journal of Asian Earth Sciences, Vol. 18, No. 6, 2000, pp. 663-673. doi:10.1016/S1367-9120(00)00017-1

[14] P. Tapponnier, G. Peltzer and R. Armijo, "On the Mechanism of Collision between India and Asia,” In: M. P. Coward and A. C. Ries, Eds., Collision Tectonics, Geological Society of London Special Publication, Vol. 19, 1986, pp. 113-157

[15] F. Hirsch, K. Ishida, T. Kozai and A. Meesook, "The Welding of Shan-Thai," Geosciences Journal, Vol. 10, 2006, pp. 195-204. doi:10.1007/BF02910364

[16] Panya Consultants Co., Ltd., "Detail Design Stage, Engineering Geological-Geotechnical Design,” Final Report, Mae Ngad-Mae Kuang Tunnel Project, Northern, 2005.

[17] K. V. Campbell, "Structural Setting and Metamorphic Grade of the Lansang Gneiss,” Newsletter of the Geological Society of Thailand, Vol. 6, No. 2, 1973, pp. 32-44

[18] A. H. G. Mitchell, "Late Permian-Mesozoic Events and the Mergui Group Nappe in Myanmar and Thailand," Journal of Southeast Asian Earth Sciences, Vol. 7, No. 2-3, 1992, pp. 165-178. doi:10.1016/0743-9547(92)90051-C

[19] I. Metcalfe, "Comment on An alternative Plate Tectonic Model for the Palaeozoic-Early Mesozoic Palaeotethyan Evolution of Southeast Asia (Northern Thailand-Burma)," Tectonophysics, Vol. 471, 2009, pp. 329-332.

[20] W. Uttamo, C. F. Elders and G. J. Nicols, "Relationships between Cenozoic Strike-Slip Faulting and Basin Opening in Northern Thailand,” In: F. Storti, R. E. Holdsworth and F. Salvini, Eds., Intraplate Strike-Slip Deformation Belts, Geological Society of London Special Publication, Vol. 210, 2003, pp. 89-108.

[21] K. Wattananikorn, J. A. Beshir and A. Nochaiwong, "Gravity Interpretation of Chiang Mai Basin, Northern Thailand: Concentrating on Ban Thung Sieo Area,” Journal of Southeast Asian Earth Sciences, Vol. 12, No. 1-2, 1995, pp. 53-64. doi:10.1016/0743-9547(95)00022-4

[22] S. Polachan and N. Sattayarak, "Strike-Slip Tectonics and the Development of Tertiary Basins in Thailand," International Symposium on Intermontane Basins: Geology and Resources, Chiang Mai, 30 January-2 February 1989, pp. 243-253.

[23] S. M. Macdonald, G. R. Barr, G. R. Dunning and W. Yaowanoiyothin, "The Doi Inthanon Metamorphic Core Complex in NW Thailand: Age and Tectonic Significance,” Journal of Southeast Asian Earth Sciences, Vol. 8 , No. 1-4, 1993, pp. 117-126.

[24] A. Mickein, "U-Pb-, Rb/Sr- und K/Ar-Untersuchungen zur Metamorphen Entwicklung und Entwicklung und Altersstellung des 'Präkambriums' in NW-Thailand,” Goettinger Arbeiten zur Geologie und Palaeontologie, No. 73, 1997, pp. 1-83.

[25] C. K. Morley, "Variations in Late Cenozoic-Recent StrikeSlip and Oblique-Extensional Geometries, within Indo- china: The Influence of Pre-Existing Fabrics,” Journal of Structural Geology, Vol. 29, No. 1, 2007, pp. 36-58. doi:10.1016/j.jsg.2006.07.003

[26] C. K. Morley, “Combined Escape Tectonics and Subduction Rollback-Back Arc Extension: A Model for the Evolution of Cenozoic Rift Basins in Thailand, Malaysia and Laos," Journal of the Geological Society of London, Vol. 158, No. 3, 2001, pp. 461-474. doi:10.1144/jgs.158.3.461

[27] C. K. Morley, N. Woganan, N. Sangkumarn, T. B. Hoon, A. Alief and M. Simmons, "Late Oligocene-Recent stress Evolution in Rift Basins of Northern and Central Thailand: Implications for Escape Tectonics,” Tectonophysics, Vol. 334, No. 2, 2001, pp. 115-150. doi:10.1016/S0040-1951(00)00300-0

[28] B. Ratanasthien, "Problems of Neogene Biostratigraphic Correlation in Thailand and Surrounding Areas,” Revista Mexicana de Ciencias Geologicas, Vol. 19, No. 3, 2002, pp. 235-241.

[29] B. P. Rhodes, J. Blum and T. Devine, "Geology of the Doi Suthep Metamorphic Core Complex and Adjacent Chiang Mai Basin,” The International Conference on Stratigraphy and Tectonic Evolution of Southeast Asia and South Pacific, Bangkok, 19-24 August 1997, pp. 305-313.

[30] B. P. Rhodes, J. Blum and T. Devine, "Structural Development of the Mid-Cenozoic Doi Suthep Metamorphic Core Complex and Western Chiang Mai Basin, Northern Thailand,” Journal of Asian Earth Sciences, Vol. 18, No. 1, 2000, pp. 97-108. doi:10.1016/S1367-9120(99)00019-X

[31] A. S. Macdonald, S. M. Barr, B. V. Miller, P. H. Reynolds, B. P. Rhodes and B. Yokart, "P-T-t Constraints on the Development of the Doi Inthanon Metamorphic Core Complex Domain and Implications for the Evolution of the Western Gneiss Belt, Northern Thailand,” Journal of Asian Earth Sciences, Vol. 37, No. 1, 2009, pp. 82-104.

[32] P. Charusiri, "Lithosphile Metallogenitic Epochs of Thailand: A Geological and Geochronological Investigation," Unpublished Ph.D. Thesis, Queen’s University, 1989.

[33] S. Kongjai and S. Singharajwarapan, "Structure and Metamorphism of the Ob Luang Gneiss, Northern Thailand," In: N. Mantajit, Ed., Proceedings of the Symposium on Geology of Thailand, Bangkok, 26-31 August 2002, p. 296.

[34] T. Harnpattanapanich, K. Trinetra and C. Sutiwanich, "Phitsanulok Thrust and Fold Belt: Geologic Evendences from Kwai Noi Dam,” Proceedings of the International Symposia on Geoscience Resources and Environments of Asian Terranes (GREAT 2008), Bangkok, 24-26 November 2008, pp. 73-83.

[35] H. Hara, K. Wakita, K. Ueno, Y. Kamata, K. Hisada, P. Charusiri, T. Charoentitirat and P. Chaodumrong, "Nature of Accretion Related to Paleo-Tethys Subduction Recorded in Northern Thailand: Constraints from mélange Kinematics and Illite Crystallinity,” Gondwana Research, Vol. 16, No. 2, 2009, pp. 310-320. doi:10.1016/j.gr.2009.01.006

[36] B. P. Rhodes, R. Perez, A. Lamjuan and S. Kosuwan, "Kinematic and Tectonic Implications of the Mae Kuang Fault, Northern Thailand," Journal of Asian Earth Sci- 
ences, Vol. 24, No. 1, 2004, pp. 79-89. doi:10.1016/j.jseaes.2003.09.008

[37] P. Tapponnier and P. Molnar, "Slip-Line Field Theory and Large-Scale Continental Tectonics,” Nature, Vol. 264 No. 5584, 1976, pp. 319-324.

[38] P. Tapponnier, G. Peltzer, A. Y. Le Dain, R. Armijo and P. Cobbold, "Propagating Extrusion Tectonics in Asia: New Insights from Simple Experiments with Plasticine,” Gelolgy, Vol. 10, No. 12, 1982, pp. 611-616.

[39] P. Chaodumrong, Y. Uk-kakimapan, S. Snansieng, S. Janmaha, S. Pradidtan and N. S. Leow, "A Review of the Tertiary Sedimentary Rocks of Thailand,” In: P. Nutyalaya, Ed., Proceedings of a Workshop on Stratigraphic Correlation of Thailand and Malaysia, Geological Society of Thailand, Bangkok/Geological Society of Malaysia, Kuala Lumpur, 1983, pp. 159-187.

[40] W. Uttamo, "Structural and Sedimentological Evolution of Tertiary Sedimentary Basins in Northern Thailand," Ph.D. Dissertation Thesis, Royal Holloway, University of London, London, 2000.

[41] Northern Petroleum Development Center, "Petroleum geology of Chiangmai Basin Interpretation Report,” Vol. 1, 2006, p. 43.

[42] C. H. Fenton, P. Charusiri and S. H. Wood, "Recent Paleoseismic Investigations in Northern and Western Thailand,” Annals of Geophysics, Vol. 46, No. 5, 2003, pp. 957-981.

[43] C. K. Morley, N. Sangkumarn, T. B. Hoon, C. Chonglakmani and J. Lambiase, "Structural Evolution of the Li Basin Northern Thailand," Journal of the Geological Society of London, Vol. 157, No. 2, 2000, pp. 483-492. doi:10.1144/jgs.157.2.483

[44] B. P. Rhodes, R. Conejo, T. Benchawan, S. Titus and R. Lawson, "Palaeocurrents and Provenance of the Mae Rim Formation, Northern Thailand: Implications for Tectonic Evolution of the Chiang Mai Basin,” Journal of the Geological Society, Vol. 162, No. 1, 2005, pp. 51-63. doi:10.1144/0016-764903-128

[45] H. W. Parker, "Planning and Site Investigation in Tunnelling," $1^{\circ}$ Congresso Brasileiro de Tuneis Estruturas Subterraneas Seminario Internacional South American Tunnelling, 2004. 